UDC 633; DOI 10.18551/rjoas.2022-01.20

\title{
RELATION OF NITROGEN, ASH CONTENT, C-ORGANIC, pH AND WATER TABLE WITH STEM DIAMETER AND HEIGHT OF ALBIZIA CHINENSIS (OSBECK) MERR.: A CASE STUDY OF PEAT SOILS IN GANDANG BARAT VILLAGE, PULANG PISAU REGENCY OF CENTRAL KALIMANTAN, INDONESIA
}

\author{
Syaifuddin*, Mahbub Muhammad, Kristianto \\ Study Program of Soil Science, Faculty of Agriculture, Lambung Mangkurat University, \\ South Kalimantan, Indonesia \\ *E-mail: syaifuddin@ulm.ac.id
}

\begin{abstract}
This research was conducted with the aim of knowing the relationship between nitrogen content, ash content, C-organic, soil pH and water table depth with stem diameter and plant height of sengon. This research was conducted from January to April 2020 at Peat Soil in Gandang Barat Village, Pulang Pisau Regency, Central Kalimantan. The method used is descriptive exploratory, namely by conducting a survey in the field at the location of peatlands where sengon is cultivated, then followed by taking soil samples in the field at a depth of $0-30 \mathrm{~cm}$ and $30-60 \mathrm{~cm}$, at a distance of 1 meter from the stem. The results showed that the nitrate content was related to the stem diameter and height of the plant and the depth of the groundwater level (GWL) was related to the plant height $(\mathrm{PH})$, but was not related to the stem diameter (SD) of the sengon plant. Nitrate at $0-30 \mathrm{~cm}$ depth and ground water level have the largest contribution to sengon $\mathrm{PH}$. The sengon equations form are $\mathrm{PH}=$ $5,036+1,060 \mathrm{~N}-\mathrm{NO}^{-}$and $\mathrm{PH}=-130,286+2,392 \mathrm{GWL}$, while for the total $\mathrm{N}$ content, ammonium, $\mathrm{pH}, \mathrm{C}$ - organic and ash content were not related to stem diameter and plant height of sengon.
\end{abstract}

\section{KEY WORDS}

Peat, nitrogen, ash content, C-organic, $\mathrm{pH}$, groundwater level.

Peatlands in Indonesia, especially in Kalimantan, are quite extensive. According to Ritung et al., (2011) the area of peatland in Kalimantan reaches 4.8 million ha and in Central Kalimantan it reaches $2,659,234$ ha. These very large areas of peatlands have potential to be developed into agricultural land and plantations; but there are some specific obstacles that are usually encountered in its management. Forest fires are a problem that is often faced on peatland, whereas according to data of the Ministry of Environment and Forestry during 2014-2019, the largest area of forest and land fires that occurred in Central Kalimantan Province reached 583,833.44 Ha in 2015.

Forest fires will cause vegetations on peatlands to be lost and opened, in addition to forest fires causing plant seeds in the soil to be damaged (Wibisono et al., 2011). Peat that has been burned will usually be overgrown by ferns and other tree plants, but this type of tree that grows naturally takes a long time to grow.

Sengon is a recommended choice as a vegetation rehabilitation plant on peatlands that have experienced fires (KLHK, 2015). Sengon can grow and develop on both wet and dry lands (Baskorowati, 2014). In one year after planting, sengon in Temanggung can grow up to $8 \mathrm{~m}$ (Santoso, 1992); while at the age of two years and three years, the growth of sengon stem diameter was $12 \mathrm{~cm}$ and $16 \mathrm{~cm}$ (Hardiyanto, 2010).

Soil acidity, nutrient availability, ash content, CEC, and organic $\mathrm{C}$ are the prominent chemical properties of peat soil (Szajdak et al., 2007; Fahmi et al., 2014). Generally, peat soils have limiting factors related to soil fertility; where this can be seen by the low availability of nutrients, low soil pH, high CEC and low KB (Najiyati et al., 2005). According to Kurnain (2005) in Dariah et al., (2015) peat ash content can also be used as a characterizing factor for peat soil fertility. The higher the ash content, the better the fertility of the peat soil (Noor et al., 2014). According to Kurnain et al., (2001) burned peat has a high ash content. 
Peat soil has a high content of organic matter (C-organic), which can reach more than $18 \%$ (Agus, 2008). The C-organic content is determined by the maturity level of the peat which the reform process is assisted through the activity of microorganisms (Agus et al., 2011; Dimitriu et al., 2010; Andersen et al., 2013). In addition, peat soil has a very high total nitrogen ( $\mathrm{N}$-total) content (Handayani, 2008); however, these nutrients cannot be utilized directly by plants.

Peat groundwater level also plays an important role in cultivating crops in order to reduce the negative impact of managing the land for agriculture. According to Sosiawan et al., (2017) the types of plants to be cultivated must be adjusted to the water level of the peat land, both for food crops and annual crops. The height of the groundwater table will greatly determine the availability of nutrients needed for plant growth.

Based on this description, it can be seen that there is a relationship between plant nutrient content, especially nitrogen, as well as other soil chemical properties such as soil $\mathrm{pH}, \mathrm{C}$-organic content, ash content with stem diameter and Sengon plant height which at the same time depend on each specific GWL. This research was conducted to see the relationship in question; to see the relationship between nitrogen nutrient content, ash content, $\mathrm{C}$-organic, $\mathrm{pH}$, at each particular groundwater level with stem diameter and plant height of sengon on peat soil.

\section{METHODS OF RESEARCH}

Soil sampling was carried out using purposive sampling based on various sizes of stem diameters and height of plants on peatlands. Determination of the sample point is done by going through the pre-survey stage in the field. The data obtained through GPS is then processed using the Geographic Information System (ArcGis 10.3). Soil samples were taken as many as fifteen points at various sizes of stem diameters and height of plants with a ground water levels of $0-30 \mathrm{~cm}$ and $30-60 \mathrm{~cm}$. Soil samples were composited taken at the root zone as much as 4 points with a distance of $1 \mathrm{~m}$ from the tree. Variables analyzed in the laboratory were 1) $\mathrm{N}$-total (Kjeldahl method); 2) available nitrogen (N-NH4+ Komres and Zweers, 1986 and N-NO3- Yang, 1998); 3) Level of ash content (Muffle Furnance); 4) soil-pH (H2O); and 5) C-organic (Walkley and Black).

Plants were sampled using purposive method, which determined according to the locations of soil samples. Variables observed were 1) stem diameter (cm); and plant height $(\mathrm{cm})$, right on the spots of soil samples which all are 15 plants.

The study was conducted in Gandang Barat Village, Pulang Pisau Regency, the Center Kalimantan, Indonesia as shown in Figure 1.

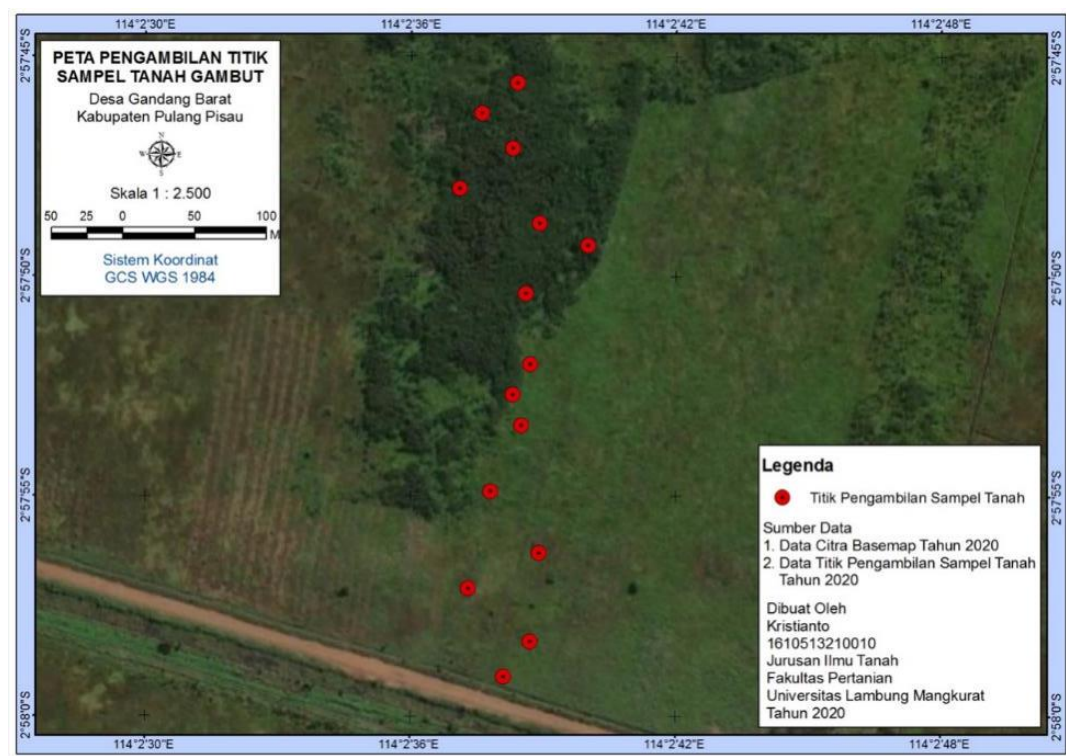

Figure 1 - Gandang Barat Village, Pulang Pisau Regency, Center of Kalimantan, Indonesia 
Data was analyzed using stepwise multiple regression executed using SPSS v25 (2020) between soil variables and plant variables in each level of depth of soil sample $0-30 \mathrm{~cm}$ and $30-60 \mathrm{~cm}$. Variable $X$ (independent variable) is more than one variable to be tested against the variable $Y$ (the dependent variable); therefore, data analysis using multiple linear regression test. Multiple linear regression analysis is usually used to see or find out the relationship between the independent variable and the dependent variable which have more than one independent variables to be tested against the dependent variable (Ghozali, 2011). The equations used for multiple linear analysis are as follows:

$$
Y=\alpha+\beta 1 X 1+\beta 2 X 2+\beta 3 X 3+\ldots .+\beta 6 X 6
$$

Where: $Y=$ Plant height $(\mathrm{PH})$ and stem diameters (SD); $\alpha=$ Regression constant; $\beta 1 \ldots \beta 7=$ Regression coefficients; $\mathrm{X} 1, \ldots, \mathrm{X} 7=\mathrm{N}$-total, N-NO3-, N-NH4+, ash content, $\mathrm{pH}, \mathrm{C}$-organic and groundwater level.

\section{RESULTS AND DISCUSSION}

Based on the results of multiple regression and correlation tests using all variables at a depth of $0-30 \mathrm{~cm}$, it is known that the variables $\mathrm{X}$ : N-total, $\mathrm{N}-\mathrm{NO} 3-, \mathrm{N}-\mathrm{NH} 4^{+}, \mathrm{pH}, \mathrm{C}$-organic, ash content; and groundwater level are simultaneous (together) no significant effect on the variable plant height $(\mathrm{F}-\mathrm{Sig}$ value $=0.101)$. It showed that only two variables have a partial

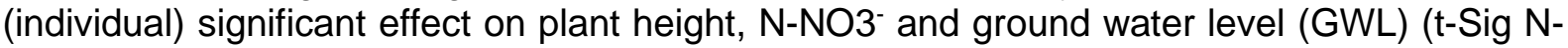
$\mathrm{NO}^{-}=0.028$ and the value of $\mathrm{t}-\mathrm{Sig}$ ground water level $\left.=0.030\right)$. Other $\mathrm{X}$ variables such as $\mathrm{N}$-total, $\mathrm{N}-\mathrm{NH}^{+}, \mathrm{pH}, \mathrm{C}$-organic and ash content partially have no significant effect on plant height (each t-Sig value for these variables is $\mathrm{t}-\mathrm{Sig}>0.05$ ). The equation and the scatter plot graph could be seen in Figures 2 and 3.

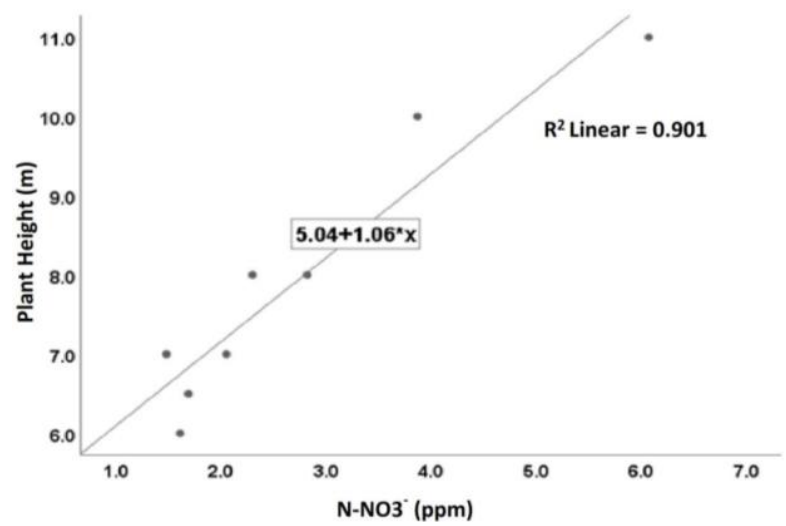

Figure 2 - Relationship between N-NO3 ${ }^{-}$and $\mathrm{PH}$ with the equation: $\mathrm{PH}=5.036+1.060 \mathrm{~N}-\mathrm{NO}-$

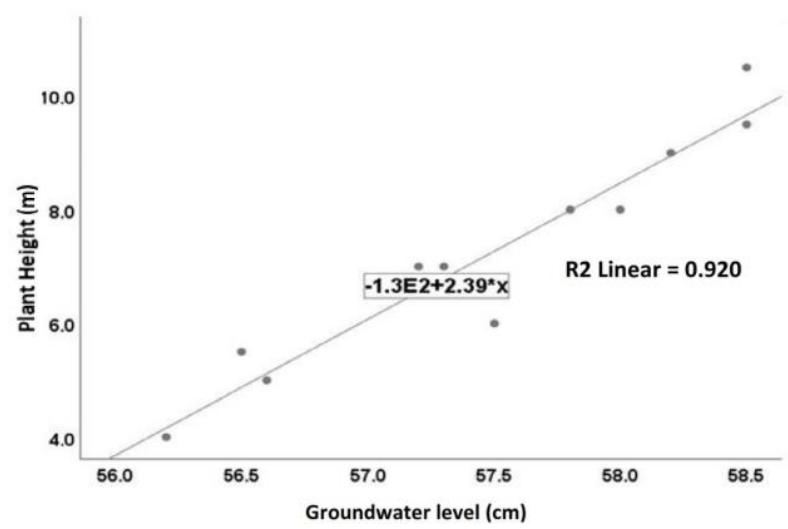

Figure 3 - Relationship of groundwater level $(\mathrm{cm})$ with plant height $(\mathrm{m})$ with the equation: $\mathrm{PH}=-130,286+2,392 \mathrm{GWL}$ 


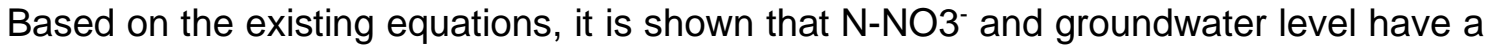
positive regression coefficient, meaning that if these variables increase, there will be an increase in plant height growth. Based on the results of the $\mathrm{F}$ test in regression analysis and

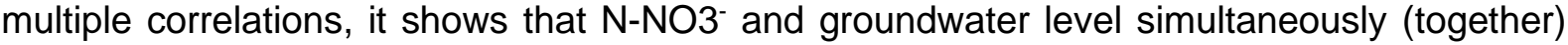
have a significant effects on plant height, this can be seen from the value of each F-Sig $<0.05$ i.e. 0.000 . Based on the results of the t-test showed that $\mathrm{N}-\mathrm{NO}^{-}$and groundwater level partially (individually) had a significant effect on plant height, this can be seen from the

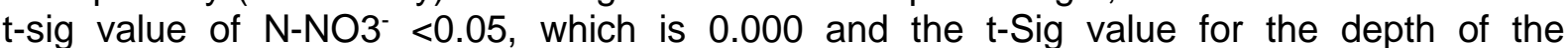
groundwater table is $<0.05$, which is 0.000 . It is also found that the coefficient of determination (R2) $\mathrm{N}^{-\mathrm{N}_{0}}{ }^{-}$is 0.901 the same as the ground water level is 0.920 , meaning that the variable $\mathrm{N}^{-\mathrm{NO}^{-}}$and the depth of the groundwater table have a contribution or influence on the variable height of each plant by $90,1 \%$ and $92.0 \%$. The value of the correlation coefficient ( $r$ ) is known that ${\mathrm{N}-\mathrm{NO}^{-}}^{-}$is 0.949 and the depth of the groundwater table is 0.959 , meaning that $\mathrm{N}^{-\mathrm{NO}^{-}}$and the depth of the groundwater table have a very strong correlation with the variable height of plants.

The research also found that using all variables at a depth of $0-30 \mathrm{~cm}$, the variables $X$ : $\mathrm{N}$-total, N-NO3-, N-NH4+, $\mathrm{pH}, \mathrm{C}$-organic, ash content, and water table simultaneously (together) has no significant effect on stem diameter (SD), this can be seen from the F-Sig value $>0.05$, which is 0.142 . The results of the t-test showed that only one variable had a partial (individual) significant effect on stem diameter, that is N-NO3, this could be seen from the value of $\mathrm{F}$-Sig $<0.05$, which was 0.048 . Other $\mathrm{X}$ variables such as $\mathrm{N}$-total, $\mathrm{N}-\mathrm{NH} 4^{+}, \mathrm{pH}$, C-organic, ash content and groundwater level have no significant effect on the stem diameter variable, which t-Sig > 0.05; The equation and the scatter plot graph (Figure 4) is as follows: Stem Diameter $=7,648+1,811 \mathrm{~N}-\mathrm{NO}^{-}$

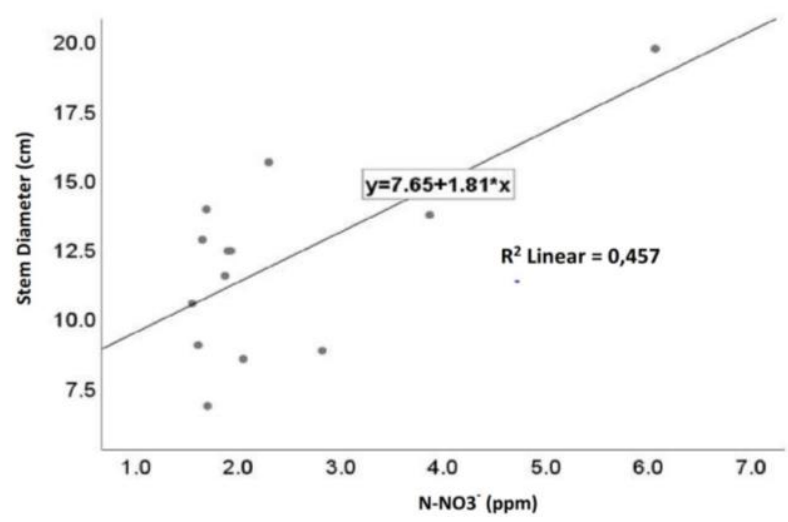

Figure 4 - Relationship of N-NO3- $(\mathrm{ppm})$ and stem diameter $(\mathrm{cm})$, with equation: $\mathrm{PH}=7,648+1,811 \mathrm{~N}-\mathrm{NO} 3$

Based on the results of multiple regression and correlation tests using all variables at a depth of $30-60 \mathrm{~cm}$, it is known that the variable $\mathrm{X}$ consists of $\mathrm{N}$-total, $\mathrm{N}-\mathrm{NO} 3^{-}, \mathrm{N}-\mathrm{NH}^{+}, \mathrm{pH}, \mathrm{C}-$ organic, and ash content simultaneously (together) have no significant effect on the variable plant height, this can be seen from the F-Sig value $>0.05$, which is 0.066 . The t-test on regression analysis and multiple correlations showed have no significant effect of soil variable at $30-60 \mathrm{~cm}$ on plant height.

Based on the results of multiple regression and correlation tests using all variables at a depth of $30-60 \mathrm{~cm}$, it is known that the $\mathrm{X}$ variable consists of $\mathrm{N}$-total, $\mathrm{N}-\mathrm{NO}{ }^{-}, \mathrm{N}-\mathrm{NH}_{4}^{+}, \mathrm{pH}$, C-organic, ash content, and groundwater level. Simultaneously (together) has no significant effect on the stem diameter variable, this can be seen from the F-Sig value $>0.05$, which is 0.419 .

Based on the results of the t-test on multiple regression and correlation, it shows that the variables $\mathrm{X}$ : N-total, $\mathrm{N}-\mathrm{NO}^{-}, \mathrm{N}-\mathrm{NH}^{+}, \mathrm{pH}, \mathrm{C}$-organic, and ash content partially (individually) have no significant effect on stem diameter variable, this can be seen from each $\mathrm{t}$-Sig value for that variable, with $\mathrm{t}-\mathrm{Sig}>0.05$. 
Based on the results of research that has been carried out, it is known that the growth of stem diameter and height of sengon plants is related to the nutrient content of nitrogen in the form of nitrate (N-NO3) at a depth of $0-30 \mathrm{~cm}$. This statement is in accordance with Wahyudi (2010) that nitrogen nutrients play a role in the process of increasing the vegetative growth of a plant. The growth of this plant height is usually influenced by apical meristem tissue whose function is to encourage the primary growth process (longitudinal growth) in plants (Wijayanti et al., (2019). According to Bar (2011) the absorption of nitrogen (N) nutrients, especially in the form of nitrate ( $\mathrm{N}^{-\mathrm{NO}^{-}}$) requires potassium $(\mathrm{K})$ paired cations, therefore compared to ammonium $\left(\mathrm{N}-\mathrm{NH}^{+}\right)$this form of nitrate nutrient can increase potassium (K) nutrient uptake, according to Raven et al., (2002) in Nihayah (2018) The enlargement of stem diameter is influenced by lateral meristem tissue that can support the secondary growth process of plants in the form of sideways division of plant cells.

Based on the results of research that has been carried out, it is known that the growth of sengon plant height is related to the height of the ground water level. Based on the research results of Sahputra et al., (2016) it is known that the groundwater level in peatlands affects the availability of nitrate. When the soil is in aerobic conditions (sufficient oxygen), it supports the nitrification process which will increase the availability of nitrate nutrients and contribute to plant height growth.

Based on the results of research that has been carried out, it is known that the growth of the stem diameter of the sengon plant is not related to the height of the groundwater level, this could be due to other factors that affect the growth of the stem diameter of the sengon plant. According to Gardner (1991) in Amalia et al. (2018), the stem diameter of a plant can increase due to the influence of cell division activity in lateral meristem tissue. Potassium is a nutrient that plays a role in the process of cell division in lateral meristem tissue, while according to Damanik et al., (2011) in aerobic soil conditions such as at the location of this study, nitrate is the dominant nutrient available.

Based on the results of research that has been carried out, it is known that the growth of stem diameter and height of sengon plants is not related to the total $\mathrm{N}$ content, this could be due to the dominant $\mathrm{N}$-total in the peat soil in a form that is not available to plants. This is in accordance with the statement of Radjagukguk (2001) that the high total $\mathrm{N}$ content in peat soils is generally caused by high levels of unavailable $\mathrm{N}$.

Based on the results of research that has been carried out, it is known that the growth of stem diameter and height of sengon plants is not related to the nutrient content in the form of ammonium (N-NH4+). This could be due to the fact that the growth of the sengon plant was supplied more by nitrate nutrients as a result of the change in the form of ammonium (N$\mathrm{NH}^{+}$) to the form of nitrate (N-NO3-) that occurred. According to Indriyanti at al., (2008) changes in the form of these nutrients can occur because the soil is in aerobic conditions, so that it will support the nitrification process which is assisted through the activity of microorganisms.

Based on the results of research that has been carried out, it is known that the growth of stem diameter and height of sengon plants is not related to soil $\mathrm{pH}$. This can happen because sengon plants have tolerance or resistance to various soil $\mathrm{pH}$ conditions. According to Nugraha et al., (2012) sengon plants can grow well at soil pH ranging from 5.5 to 7.0. In addition, according to Soerianegara et al., (1993) in Krinawati (2011) sengon plants can grow in various types of soil, even on soils that have low $\mathrm{pH}$ conditions (acidic) or on soils that contain salt.

Based on the results of research that has been carried out, it is known that the growth of stem diameter and height of sengon plants is not related to organic $C$ content. This can happen because the existing organic $\mathrm{C}$ content cannot be directly absorbed by plants, so this organic $\mathrm{C}$ must undergo a mineralization process first by soil microorganisms so that it can be converted into available forms of nutrients or can be absorbed by plants. This statement is in accordance with Atmojo (2003) that the mineralization process will be related to the availability of nutrients needed by plants.

Based on the results of research that has been carried out, it is known that the growth of stem diameter and height of sengon plants is not related to the ash content. This could 
happen because the composition of the peat soil at the study site was dominated by organic soil material. This is in accordance with the statement of Agus et al. (2008), that peat soil is soil that can be formed from plant remains that have not been completely decomposed, thus making peat soil more dominated by organic soil material when compared to minerals.

\section{CONCLUSION}

Based on the research that has been done, it can be concluded that the nitrate content at a depth of $0-30 \mathrm{~cm}$ is related to the stem diameter and height of the sengon plant and the ground water level is also related to the height of the sengon plant, but not related to the stem diameter of the sengon plant. Ground water level and nitrate have the largest contribution to sengon plant height, the form of the equation is Plant height $=-130,286+$ 2,392 groundwater level; and Plant height $=5.036+1.060 \mathrm{~N}-\mathrm{NO} 3$. Total $\mathrm{N}$ content, ammonium, C-organic, $\mathrm{pH}$ and ash content were not related to stem diameter and plant height of sengon.

\section{REFERENCES}

1. Agus, F. and I.G.M. Subiksa. 2008. Lahan Gambut: Potensi untuk Pertanian and Aspek Lingkungan. Booklet. Balai Penelitian Tanah (Ind. Soil Res. Inst.) and World Agroforestry Centre (ICRAF) Asia, Bogor. Indonesia.

2. Agus, F., K. Hairiah, and A. Mulyani. 2011. Measuring Carbon Stock in Peat Soil: Practical Guidelines. World Agroforestry Centre-ICRAF SEA Regional Office and Indonesian Center for Agric. Land Resourc. Res. and Dev., Bogor, Indonesia.

3. Andersen, R., C. Wells., M. Macrae, and J. Price. 2013. Nutrient Mineralisation and Microbial Functional Diversity in a Restoration. Soil Biology \& Biochemistry 64:37-47.

4. Atmojo, S.W. 2003. Peranan Bahan Organik Terhadap Kesuburan Tanah and Upaya Pengelolaannya. Disertasi. Universitas Sebelas Maret. Surakarta.

5. Bar, T.A. 2011. The Effect of Nitrogen Form on Interaction with Potassium. Internasional Potash Institute.

6. Baskorowati, L. 2014. Budidaya Sengon Unggul (Falcataria moluccana) Untuk Pengembangan Hutan Rakyat. IPB Press. Bogor.

7. Damanik, M.B.B., E.H. Bachtiar., Fauzi., Sarifuddin, and H. Hamidah. 2011. Kesuburan Tanah and Pemupukan. Usu Press. Medan.

8. Dimitriu, P.A., D. Lee, and S.J. Grayston. 2010. An Evaluation of the Functional Significance of Peat Microorganisms Using a Reciptrocal Transplant Approach. Soil Biology and Biochemistry 42:65-67.

9. Gardner, F.P., B. Pearce, and R.L. Mitchell. 1991. Fisiologi Tanaman Budidaya. di dalam: Amalia, W., N. Hayati, and Kusrinah. 2018. Perbandingan Pemberian Variasi Konsentrasi Pupuk sari Limbah Cair Tahu Terhadap Pertumbuhan Tanaman Cabai Rawit (Capsicum Fratescens L.). Prodi Pendidikan Biologi Universitas Islam Negeri Walisongo. Semarang. Jurnal Biologi and Biologi Terapan 1 (1).

10. Fahmi, A., B. Radjagukguk, and B.H. Purwanto. 2014. Interaction of Peat Soil and Sulphidic Material Substratum: Role of Peat Layer and Groundwater Level Fluctuations on Phosphorus Concentration. Journal Soil Trop. 19(3):161-169.

11. Handayani, I.P. 2008. Tinjauan Funsi Gambut Sebagai Bahan Ekstraktif, Media Budidaya and Peranannya dalam Retensi Karbon. Wetlands International.

12. Hardiyanto, E.B. 2010. Faktor yang Berpengaruh pada Produktivitas and Kualitas Kayu Sengon. Fakultas Kehutanan UGM. Yogyakarta.

13. Indriyati, L.T., S. Supiandi., L.K. Kadarusman., R. Situmorang., Sudarsono, and W.H. Sisworo. 2008. Nitrogen Transformation in Flooded Soil: Aplication of Rice Straw and Rice Straw Composts. Journal Soil Trop, 13(3), 189-197.

14. Kementerian Lingkungan Hidup and Kehutanan (KLHK). 2015. Pedoman Pemulihan Ekosistem Gambut. Jakarta. 
15. Kurnain, A., T. Notohadikusumo, B. Radjagukguk, and Hastuti. 2001. The State of Decomposition of Tropical Peat Soil under Cultivated and fire Damage Peatland. di dalam: Rieley, and Page (Eds). Jakarta Symposium Proceeding on Peatlands for People: Natural Resources Functions and Sustainable Magagement.

16. Kurnain, A. 2005. Dampak Kegiatan Pertanian and Kebakaran atas Watak Gambut Ombrogen. di dalam: Dariah, A., E. Maftuah, and Maswar. 2015. Karakteristik Lahan Gambut. Balai Penelitian Tanah and Balai Penelitian Pertanian Lahan Rawa. Banjarbaru.

17. Najiyati, S., L. Muslihat, and N.N. Suryadiputra. 2005. Panduan Pengelolaan Lahan Gambut untuk Pertanian Berkelanjutan. Proyek Climate Change, Forests and Peatlands in Indonesia. Wetlands International-Indonesia Programme and Wildlife Habitat Canada. Bogor, Indonesia.

18. Nugraha, G., R. Herawatiningsih, and J. Nugroho. 2012. Evaluasi Kesesuaian Lahan Gambut Untuk Tanaman Sengon (Paraserianthes falcataria (L) Nielsen) di Desa Kuala Dua Kecamatan Sungai Raya Kabupaten Kubu Raya. Fakultas Kehutanan Universitas Tanjungpura. Pontianak.

19. Noor, M. 2001. Pertanian Lahan Gambut: Potensi and Kendala. Kanisius. Yogyakarta.

20. Radjagukguk, B. 2001. Perspektif Pemasalahan and Konsepsi Pengelolaan Lahan Gambut Tropika untuk Pertanian Berkelanjutan. Fakultas Pertanian Universitas Gadjah Mada. Yogyakarta.

21. Raven, and Johnson. 2002. Biology (6th ed). di dalam Nihayah, A.Z. 2018. Efektivitas Model Pembelajaran Skimming, Mind Mapping, Questioning, Exploring, Writing, and Communicating (Simas Eric) Terhadap Motivasi Hasil Belajar Biologi Siswa Kelas XI IPA SMA 2 Banguntapan. Skripsi. Prodi Pendidikan Biologi Universitas Islam Negeri Sunan Kalijaga. Yogyakarta.

22. Sahputra, R., Wawan, and E. Enom. 2016. Pengaruh Kedalaman muka air tanah Tanah and Bahan Organik Terhadap Ketersediaan Hara and Pertumbuhan Tanaman Kelapa Sawit (Elaeis Guineensis Jacq) di Lahan Gambut. Fakultas Pertanian Universitas Riau. Riau.

23. Santoso. 1992. Budidaya Sengon. Kanisius. Jakarta.

24. Sosiawan, H., B. Kartiwa., W.T. Nugroho, and H. Syahbuddin. 2014. Variasi Temporal and Spasial Tinggi Muka Air Gambut Lokasi Demplot ICCTF Jabiren Kalimantan Tengah. Balai Penelitian Agroklimat and Hidrologi. Bogor -Badan Penelitian and Pengembangan Pertanian.

25. Soerianegara, I. and R.H.M.J. Lemmens. 1993. Plant Resources of South-East Asia.

26. Pudoc Scientific Publishers. di dalam: Krisnawati, H., E. Varis, M. Kallio, and $M$. Kanninen. 2011. Paraserianthes Facultaria (L.) Nielsen: Ekologi, Silvikultur and Produktivitas. CIFOR. Bogor.

27. Szajdak, L., T. Brandyk, and J. Szatylowicz. 2007. Chemical Properties of Different Peat Marsh Soil from the Biebrza River Valley. Agronomy Research 5:165-174.

28. Wahyudi. 2010. Petunjuk Praktis Bertanam Sayuran. Agromedia Pustaka. Jakarta. Wibisono, I.T., L.Soboro, and I.N.N. Suryadiputra. 2011. Keanekaragaman Jenis Tumbuhan di Hutan Rawa Gambut. Seri Pengelolaan Hutan and Lahan Gambut. Wetland Internasional, Canadian Internasional Development Agency, Kementerian Kehutanan.

29. Wijayanti, P., E.D. Hastuti, and S. Haryanti. 2019. Pengaruh Masa Inkubasi Pupuk dari Air Cucian Beras Terhadap Pertumbuhan Tanaman Sawi Hijau (Brassica Juncea L.). Universitas Diponegoro. Semarang. Jurnal Buletin Anatomi and Fisiologi 4 (1). 